\title{
Revisiting the environmental rewards of economic freedom
}

\author{
Christopher Andrew Hartwell $^{1 *} \cdot$ Don L. Coursey ${ }^{2}$ \\ ${ }^{I}$ Department of International Management, Kozminski University, Poland and CASE - Center for Social and \\ Economic Research \\ ${ }^{2}$ The Harris School of Public Policy, University of Chicago, USA
}

Received: 24 December 2014

Revised: 10 February 2015

Accepted: 18 February 2015

\begin{abstract}
Previous research has detailed the positive link between economic freedom and environmental and public health outcomes. However, advances in the interim in our knowledge of how economic freedom affects various economic outcomes, as well as in the quantification of various economic institutions, calls for a re-examination of the results. Compiling a new panel data set that picks up where the prior analysis left off, we utilize FE-GLS methods to find that economic freedom writ large lead to a cleaner and healthier environment. Additionally, economic freedom as manifested in contracting institutions also correlates with positive health and environmental outcomes, even in the presence of differing control sets.
\end{abstract}

Keywords: contracting institutions, economic freedom, environmental improvement, public health outcomes

JEL Classification Codes: Q53, E02, I18

\section{Introduction}

How does economic freedom impact environmental and public health outcomes? Fifteen years ago, we (Coursey and Hartwell, 2000) examined this relationship for 130 countries from 1960-92 and found that, by nearly every environmental and public health indicator, greater economic freedom led to better outcomes. For most metrics, we could discern an environmental Kuznets Curve (EKC), with the strongest correlations between freedom and environmental improvement found for access to sanitation, metal intensity, electrical cleanliness, and life expectancy. Indeed,

\footnotetext{
* Corresponding author. E-mail: chartwell@kozminski.edu.pl.

Citation: Hartwell, C.A. and Coursey, D.L. (2015) Revisiting the environmental rewards of economic freedom, Economics and Business Letters, 4(1), 36-50.
} 
the only real aberration was in $\mathrm{CO} 2$ emissions (following Yandle et. al., 2000, theory of differential impact of local versus dispersed pollutants), which seemed to grow linearly with economic freedom.

In the intervening years since this analysis, the economics discipline has refined its understanding of the interactions between economic freedom and economic outcomes (including inter alia de Haan and Sturm, 2000, McMullen et. al., 2008, and Williamson and Mathers, 2011). In particular, the examination of institutions has made important strides, including in the quantification of various economic institutions (Bashir and $\mathrm{Xu}, 2014$ ), enabling us to understand better the channels in which economic freedom can impact environmental, as well as economic, outcomes.

However, economic freedom itself has also taken a large step back from the heady days of 2000. The changes have been especially pronounced in the environmental realm. Calls for massively increased regulations to reduce $\mathrm{CO} 2$ emissions have gone hand-in-hand with a general expansion of developed-country environmental regulations; for example, the US Environmental Protection Agency now employs over 17,000 people and administers regulations spread over 32 printed volumes. Moreover, the shift towards "sustainable development" in policymaking has also created an inherent tension with the idea of economic freedom (Falkner, 2007), prioritizing environmental outcomes at the expense of growth. Empirical analyses from Cole et. al. (2005) and Halkos and Paizanos (2013) have lent credibility to the idea that greater regulation and greater government spending is necessary for controlling pollutants.

The purpose of this note is thus to update the work done in the earlier research to see if the earlier relationships regarding freedom and environmental and health improvements still hold through the 1990s and 2000s. Drawing on the advances in the literature on freedom and especially on institutions, including more robust controls and an attempt to control for endogeneity, we find that the correlation between economic freedom and better environmental and public health outcomes remains strong. We conclude that the way forward for environmental policymaking should concentrate on improving property rights and limiting the power of the state, rather than expanding it.

\section{Methods}

The underlying hypothesis for this work is that economic freedom would lead to better environmental outcomes through two separate channels. First, more economically open societies should be able to harness the superior abilities of the market in disseminating and coordinating information relating to the relative scarcity of resources, thus alleviating the issues of imperfect information that are associated with environmental usage. Secondly, we believe that freer countries will be characterized by more competition, which in turn will lead to greater innovation among industries in order to conserve scarce resources. Open economies can realistically be assumed to see perhaps higher levels of materials usage in opening stages of development, tapering off as technological innovation takes over from materials accumulation (following the EKC hypothesis, see Grossman and Kruger, 1993, and more recent work from Dasgupta et. al., 2002, and Carson, 2010).

In order to extend our earlier analysis, for this paper we model environmental outcomes as a function of economic freedom, macroeconomic variables, and time (to capture microeconomic and technological advances not captured in the freedom or macroeconomic variables). The original model as it appeared in Coursey and Hartwell (2000) was shown as: 


$$
Y_{i t}=\alpha M A C R O_{i t}+\beta F R E E D O M_{i t}+\operatorname{TIME}_{i}+\varepsilon_{i t}
$$

where $\mathrm{Y}$ was the specific environmental and public health outcome in question, MACRO referred to the matrix of macroeconomic controls, FREEDOM was captured using Freedom House's civil liberty index, and TIME was a simple time dummy to capture trend and technological effects.

For this exercise, the basic structure shown in Equation 1 has been expanded to encompass several other variables, as well as different dimensions of economic freedom:

$$
\begin{aligned}
& Y_{i t}=\alpha M_{\text {MCRO }}{ }_{i t-1}+\gamma \text { STRUCTURE } \\
& i t-1
\end{aligned}
$$

The panoply of environmental and public health outcomes that were used in the earlier paper as the $\mathrm{Y}$ variable remain, with minor exceptions, the same for the analysis here (Table 1). In many instances, we choose to use "materials use intensity" (Bernardini and Galli, 1993; Jalas, 2002) rather than levels of emissions, to capture environmental efficiency rather than gross output; intensity is defined here (as originally in Malenbaum, 1978, and more recently in West et. al., 2014) as the "apparent consumption" of a particular good (production plus imports less exports) per unit of GDP.

MACRO, as used in our original paper, focused on only a few macroeconomic and demographic determinants of pollution in the style of growth regressions in vogue at the time (building on Barro, 1991, and continuing through Levine and Renelt, 1992, and Fischer, 1993, among many others). The three most prominent controls were: log of per capita GDP, with higher levels of income tending to be associated with lower levels of pollution (Selden and Song, 1994); secondary school enrollment, as a more-educated populace would more likely demand higher environmental outcomes (Martins et. al., 2004); and population density, which we used as a proxy for urbanization and geographical dispersion that could either increase the impact of human activities in a smaller area and increase pollution, or perhaps create economies of scale in pollution abatement (making pollution easier to clean).

Borrowing from recent advances in the determinants of environmental quality (see especially Fuchs, 2003, and Gassebner, Lamlay and Sturm, 2010), we are extending these variables in this brief re-examination to include various attributes of the structure of the economy. Specifically, we include value-added to GDP from agriculture (on the basis that water pollution might be increased in the presence of higher-intensity agriculture); value-added to GDP from manufacturing (similarly, air emissions should increase with higher levels of heavy industry); and trade intensity (or openness, defined as total exports + imports over GDP).

The biggest change here, however, regards the core of our thesis, and that is the manner in which we measure economic freedom. In particular, our original work utilized Freedom House's civil liberty index, which ranks rule of law, human rights, and personal autonomy and economic rights on a scale of 1 to 7 (with higher values corresponding to more freedom). While this index was useful in 2000 to show the effects of various extreme measures of freedom or repression over the time period in question, the scale also brought together countries that had very different levels of environmental regulation under the same heading. In this note, we will try to take a more nuanced view of freedom than was available at the time of our first publication. In addition 
to the Freedom House Index, we utilize the Fraser Economic Freedom of the World Index (Gwartney et. al., 2014) and the Heritage Foundation's Index of Economic Freedom, both of which have much better coverage over the period 1990-2011.

But perhaps it is not the larger idea of economic freedom that matters for these outcomes, but a separate facet of the institutional framework of a country that contributes to overall economic freedom; after all, the measures shown above are a combination of political and institutional outcomes that may have differing impacts on different environment or health variables. Taking this into account, and building off of the substantial advances in the quantitative institutional economics literature over the past decade (Voigt, 2013; Shirley, 2013), we include specific facets of economic freedom.

The first of these is freedom to contract, or property rights taken more broadly. In terms of its expected relationship with environmental outcomes, a healthy respect for property rights should alleviate the "tragedy of the commons" (Hardin, 1968; Ostrom, 1990) and lead to better environmental results. To capture property rights, we utilize an objective indicator known as "contract-intensive money." Taken from Clague et. al. (1997) and as used in Hartwell (2013), contract-intensive money is defined as:

$$
\frac{(M 2-C)}{M 2}
$$

where M2 is a broad definition of money supply and C is the amount of currency held outside of formal financial institutions. The ratio described by equation 2 should translate into a definition of property rights, as countries with higher levels of property rights would see higher proportions of currency held in formal institutions instead of in cash, under mattresses, or elsewhere.

A second measure of the institutional framework that will be included is political freedom, captured here by the Polity IV executive constraints indicator (with higher values meaning more constraints on a country's executive). Theoretically, political freedom should translate into the development of better quality institutions (Weingast, 1995; Levinson, 2010), and these institutions can translate "constantly evolving environmental preferences" into action "more quickly in an open regime" (Coursey and Hartwell, 2000:4). Previous empirical work from Congleton (1992), Barrett and Graddy (2000) and Lamla (2009) have confirmed that political indicators all have a direct influence on pollution levels, and we believe that their indirect influence on the development of other institutions in an economy will also impact environmental efficiency.

The exigencies of our dataset and the interactions expected between freedom, macroeconomic variables, and environmental/health outcomes also call for a sophisticated econometric approach. Our earlier work utilized both a pooled OLS and a fixed-effects specification, but advances in econometrics and the difficulties in panel data argue for a reappraisal of this approach. For this examination, we utilize a panel GLS estimator using country-level dummy variables to control for all unobserved time-invariant differences among the countries in our data (an approach commonly known as FGLSDV, or feasible GLS with dummy variables, as in Auberger, 2005; Yakovlev (2007); Acs et. al. (2012) and Peša and Festić, 2014). This approach will correct for heteroskedasticity with robust standard errors and common AR(1) effects (determined via data 
diagnostics to be problematic), ${ }^{1}$ as well as attempt to eliminate causality issues through lagged explanatory variables (as shown in equations 2 and 3 );

As a check on these results, and given the possibility of endogeneity bias in the results that cannot be corrected via use of lags, we utilize an alternate set of factor endowments (as in Cole and Elliott 2003) in place of macroeconomic variables. Such an approach eliminates the need for dynamic panel estimation, given the exogeneity of such endowments in our models.

\section{Data}

The dataset in this paper covers 194 countries from 1990-2011, although not every dependent variable is available for every year/country pair. Table 1 shows the full list of dependent variables and their sources; in regards to the dependent variables, the economic freedom indicators are taken from their namesake institutions, while contract-intensive money was calculated from data provided by the IMF's International Financial Statistics. All macroeconomic variables and the factor endowment of land/population come from the World Bank's World Development Indicators, while the capital/labor endowment is derived from the Penn World Tables.

Table 1. Environmental and public health outcomes: the Y variables

\begin{tabular}{|c|c|c|}
\hline Indicator & Definition & Source \\
\hline $\begin{array}{l}\text { Access to Safe } \\
\text { Water }\end{array}$ & $\begin{array}{l}\% \text { of the population with reasonable access to an } \\
\text { adequate amount of water from an improved source } \\
\text { (household connection or protected well or spring) }\end{array}$ & WDI \\
\hline $\begin{array}{l}\text { Access to } \\
\text { Sanitation }\end{array}$ & $\begin{array}{l}\% \text { of the population with at least adequate access to } \\
\text { disposal facilities that can effectively prevent } \\
\text { contact with human waste }\end{array}$ & WDI \\
\hline "Cleanliness" & $\begin{array}{l}\text { Total CO2 emissions in kilo tons divided by total } \\
\text { electric output, in kilowatts }\end{array}$ & $\begin{array}{l}\text { Author's calculations from } \\
\text { Datamonitor and WDI data }\end{array}$ \\
\hline Coal Intensity & $\begin{array}{l}\text { Coal Consumption + Imports - Exports /GDP } \\
\text { (Constant } 2000 \text { US\$) }\end{array}$ & $\begin{array}{l}\text { Author's calculations from } \\
\text { Datamonitor and WDI data }\end{array}$ \\
\hline Electrical Intensity & $\begin{array}{l}\text { Electrical Power Consumption + Imports - Exports } \\
\text { /GDP (Constant } 2000 \text { US\$) }\end{array}$ & $\begin{array}{l}\text { Author's calculations from } \\
\text { Datamonitor and WDI data }\end{array}$ \\
\hline Gas Intensity & $\begin{array}{l}\text { Natural gas consumption + Imports - Exports/ GDP } \\
\text { (Constant } 2000 \text { US\$) }\end{array}$ & $\begin{array}{l}\text { Author's calculations from } \\
\text { Datamonitor and WDI data }\end{array}$ \\
\hline
\end{tabular}

\section{Results}

Tables 2 and $3 \mathrm{a}$ and $\mathrm{b}$ show the results of the GLS econometric estimation of the relationship between economic freedom and economic institutions on the one hand and public health (Table 2) and environmental outcomes (Tables $3 a$ and $b$ ) on the other. The first issue we can see is the wide variation in coverage of the different institutional/freedom indicators: in particular, the Fraser series has about half the coverage of the Heritage Foundation, and a third of the contract-

\footnotetext{
${ }^{1}$ Other routine diagnostics regarding stationarity were also carried out via a Phillips-Peron test, robust to serial correlation and including a trend. All variables were found to be stationary.
} 
intensive money and Freedom House indices. This reality causes some issues with the estimations as we will see below.

Leaving this statistical issue aside, the picture that is painted by the results is a strong one, with vivid green colors. Table 2 shows that by nearly every metric of freedom or institutional quality (with the puzzling exception of the Fraser Institute), more freedom leads to better access to clean water. On the other hand, access to sanitation is largely driven by other metrics, although, somewhat oddly, increases in property rights and in the Fraser measure of freedom are negatively and significantly correlated with access to sanitation. We surmise that either the effects captured by the various indicators are very different (in that the Fraser and property rights indicators reflect facets of freedom not amenable to increased sanitation access), or, simply, that greater property rights means better but more exclusive latrines.

The results are less ambiguous when it comes to our environmental intensity indicators (Tables $3 \mathrm{a}$ and $\mathrm{b}$ ), where cleanliness and intensity of consumption in coal and gas improves as freedom and contracting and rule of law institutions improve. ${ }^{2}$ Electricity intensity seems to show deterioration no matter which metric is utilized, apart from civil liberties, which could be capturing a more holistic view of a country's institutional system than the other variables of freedom. $^{3}$ A possible reason for this result is that countries can have extensive economic freedom in other spheres, but still have highly regulated state monopolies in electric generation and supply.

The behavior of freedom and electrical intensity raises a further interesting question: given that these freedom indices are aggregations of many different dimensions of economic freedom (Rode and Coll, 2012), could there be a specific component that is primarily driving environmental improvement? To test this, we have re-run the environmental regressions with the five components of the Fraser Economic Freedom of the World Index (Tables 4a and 4b). As theory would predict, property rights appear to contribute to the biggest improvement in environmental cleanliness, while smaller governments result in more efficient electricity, gas, and coal usage. Perhaps surprisingly, freedom to trade results in higher materials use per unit of output across most metrics, although it is possible that this result is attributable to the higher technology embodied in exports. Finally, more labor market and business freedom (embodied in the "regulation" indicator) has a highly significant efficiency effect on gas and coal intensity. As a final check against these results, and to guard against endogeneity of the macroeconomic variables, I select the significant environmental regressions from each Y variable and substitute endowment data instead of macroeconomic variables (Table 5). ${ }^{4}$ Table 5 confirms that the electricity specification may not be perfect (although capital to labor ratios do have a significant influence on electrical intensity), but for the other models, the significance of economic freedom for environmental outcomes continues to hold.

\section{Concluding Remarks}

These results show that higher levels of economic freedom continue to be associated with better environmental and public health outcomes. Using more nuanced indicators for freedom and

\footnotetext{
${ }^{2}$ Given that these intensity indicators measure the amount of $\mathrm{X}$ consumed versus output of GDP, negative signs imply less use of a resource per $\$$ of output and are thus more desirable.

${ }^{3}$ An alternate measure of political freedom, the Polity IV democracy/autocracy indicator, was used (not reported) and showed similar results as civil liberties.

${ }^{4}$ For sake of space, the public health regressions are not included here.
} 
economic institutions, we can ascertain that freedom does indeed have environmental rewards, although (as in Doucouliago and Ulubasoglu, 2006) the results are sensitive to which measure of "freedom" and which institutional indicator is utilized. The implications of this research continue to point the way towards alternative solutions to increased government involvement in environmental protection, along the lines of Khanna (2001) and in a market-based manner. In fact, smaller governments and increased property rights (coupled with economic growth) appear to be the key factors for environmental improvement.

Acknowledgements. The authors wish to thank the Editor-in-Chief and three anonymous referees for their constructive comments. We also thank Mikhail Volkov for excellent research assistance.

\section{References}

Acs, Z.J., Audretsch, D.B., Braunerhjelm, P. and Carlsson, B. (2012) Growth and entrepreneurship, Small Business Economics, 39(2), 289-300.

Auberger, A. (2005) Forecasts of the 2004 French European election, Swiss Political Science Review, 11(3), 61-78.

Barrett, S. and Graddy, K. (2000) Freedom, growth, and the environment, Environment and Development Economics, 5(4), 433-456.

Barro, R.J. (1991) Economic growth in a cross section of countries, The Quarterly Journal of Economics, 106(2), 407-443.

Bashir, M.F. and Xu, C. (2014) Impact of political freedom, economic freedom and political stability on economic growth, Journal of Economics and Sustainable Development, 5(22), 59-67.

Bernardini, O. and Galli, R. (1993) Dematerialization: long-term trends in the intensity of use of materials and energy, Futures, 25(4), 431-448.

Carson, R.T. (2010) The environmental Kuznets curve: seeking empirical regularity and theoretical structure, Review of Environmental Economics and Policy, 4(1), 3-23.

Clague, C., Keefer, P., Knack, S. and Olson, M. (1997) Institutions and economic performance: property rights and contract enforcement, in Clague, C. (ed.) Institutions and Economic Development, Baltimore: Johns Hopkins Press, 67-90.

Cole, M.A. and Elliott, R.J.R. (2003) Determining the trade-environment composition effect: the role of capital, labor and environmental regulations, Journal of Environmental Economics and Management, 46(3), 363-383.

Cole, M.A., Elliott, R.J. and Shimamoto, K. (2005) Industrial characteristics, environmental regulations and air pollution: an analysis of the UK manufacturing sector, Journal of Environmental Economics and Management, 50(1), 121-143.

Congleton, R.D. (1992) Political institutions and pollution control, Review of Economics and Statistics, 74(3), 412-421.

Coursey, D.L and Hartwell, C.A. (2000) Environmental outcomes and openness: a historical and international comparison, Working Paper No. 0010, Harris School of Public Policy Studies, University of Chicago.

Dasgupta, S., Laplante, B., Wang, H. and Wheeler, D. (2002) Confronting the environmental Kuznets curve, Journal of Economic Perspectives, 16(1), 147-168.

De Haan, J. and Sturm, J.E. (2000) On the relationship between economic freedom and economic growth, European Journal of Political Economy, 16(2), 215-241. 
Doucouliagos, C. and Ulubasoglu, M.A. (2006) Economic freedom and economic growth: does specification make a difference?, European Journal of Political Economy, 22(1), 60-81.

Falkner, R. (2007) The political economy of 'normative power' Europe: EU environmental leadership in international biotechnology regulation, Journal of European Public Policy, 14(4), 507-526.

Fischer, S. (1993) The role of macroeconomic factors in growth, Journal of Monetary Economics, 32(3), 485-512.

Fuchs, D.A. (2003) An institutional basis for environmental stewardship, Amsterdam: Springer Netherlands.

Gassebner, M., Lamla, M.J. and Sturm, J-E. (2010) Determinants of pollution: what do we really know?, Oxford Economics Papers, 63(3), 568-595.

Gwartney, J., Lawson, R. and Samida, D. (2014) Economic freedom in the world: 2010 annual report, Vancouver: Fraser Institute.

Halkos, G.E., and Paizanos, E.A. (2013) The effect of government expenditure on the environment: an empirical investigation, Ecological Economics, 91(1), 48-56.

Hardin, G. (1968) The tragedy of the commons, Science, 162(3859), 1243-1248.

Hartwell, C.A. (2013) Institutional barriers in the transition to market: explaining performance and divergence in transition economies, Basingstoke: Palgrave Macmillan.

Jalas, M. (2002) A time use perspective on the materials intensity of consumption, Ecological Economics, 41(1), 109-123.

Khanna, M. (2001) Non-mandatory approaches to environmental protection, Journal of Economic Surveys, 15(3), 291-324.

Lamla, M.J. (2009) Long-run determinants of pollution: a robustness analysis, Ecological Economics, 69(1), 135-144.

Levine, R. and Renelt, D. (1992) A sensitivity analysis of cross-country growth regressions, American Economic Review, 82(4), 942-963.

Levinson, D.J. (2010) Parchment and politics: the positive puzzle of constitutional commitment, Harvard Law Review, 124(3), 657-746.

Malenbaum, W. (1978) World demand for raw materials in 1985 and 2000, New York: McGraw-Hill.

Martins, M.C.H., Fatigati, F.L., Vespoli, T.C., Martins, L.C., Pereira, L.A.A., Martins, M.A. and Braga, A.L.F. (2004) Influence of socioeconomic conditions on air pollution adverse health effects in elderly people: an analysis of six regions in Sao Paulo, Brazil, Journal of Epidemiology and Community Health, 58(1), 41-46.

McMullen, J.S., Bagby, D. and Palich, L.E. (2008) Economic freedom and the motivation to engage in entrepreneurial action, Entrepreneurship Theory and Practice, 32(5), 875-895.

Ostrom, E. (1990) Governing the commons: the evolution of institutions for collective action, Cambridge: Cambridge University Press.

Peša, A. R. and Festić, M. (2014) Panel regression of stock market indices dynamics in southeastern European economies, Economic Research-Ekonomska Istraživanja, 27(1), 673688.

Rode, M. and Coll, S. (2012) Economic freedom and growth. Which policies matter the most?, Constitutional Political Economy, 23(2), 95-133.

Selden, T.M. and Song, D. (1994) Environmental quality and development: is there a Kuznets curve for air pollution?, Journal of Environmental Economics and Management, 27(2), $147-162$. 
Shirley, M.M. (2013) Measuring institutions: how to be precise though vague, Journal of Institutional Economics, 9(1), 31-33.

Voigt, S. (2013) How (not) to measure institutions, Journal of Institutional Economics, 9(1), 126.

Weingast, B.R. (1995) The economic role of political institutions: market-preserving federalism and economic development, Journal of Law, Economics, \& Organization, 11(1), 1-31.

West, J., Schandl, H., Krausmann, F., Kovanda, J. and Hak, T. (2014) Patterns of change in material use and material efficiency in the successor states of the former Soviet Union, Ecological Economics, 105, 211-219.

Williamson, C.R. and Mathers, R.L. (2011) Economic freedom, culture, and growth, Public Choice, 148(3-4), 313-335.

Yakovlev, P. (2007) Arms trade, military spending, and economic growth, Defence and Peace Economics, 18(4), 317-338.

Yandle, B., Vijayaraghavan, M. and Bhattarai, M. (2000) The environmental Kuznets curve: a primer, The Property and Environment Research Center, available on-line at: http://www.perc.org/articles/article688.php. 
Table 2. Public health outcomes as a function of freedom and institutions

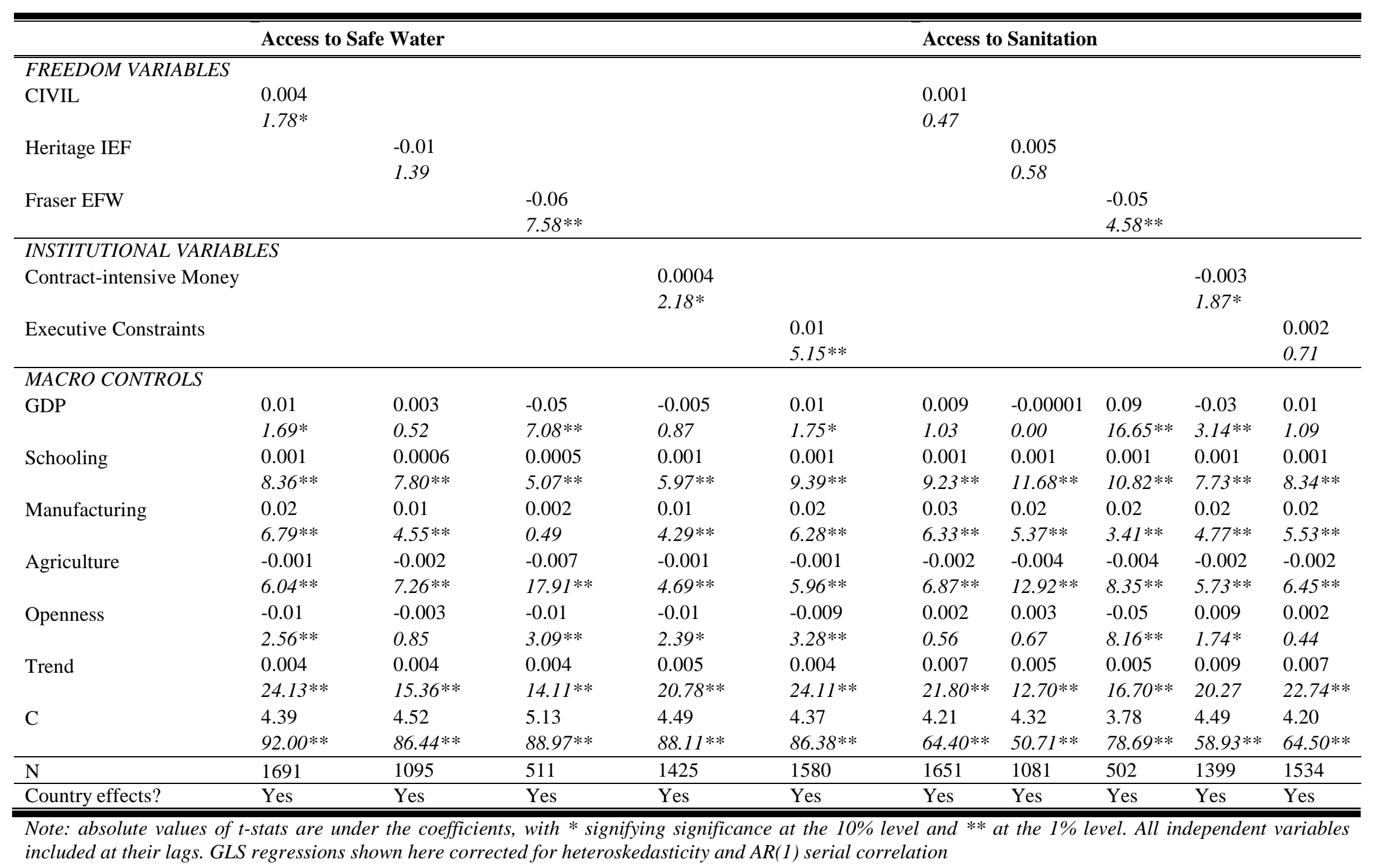


Table 3a. Environmental outcomes as a function of freedom and institutions

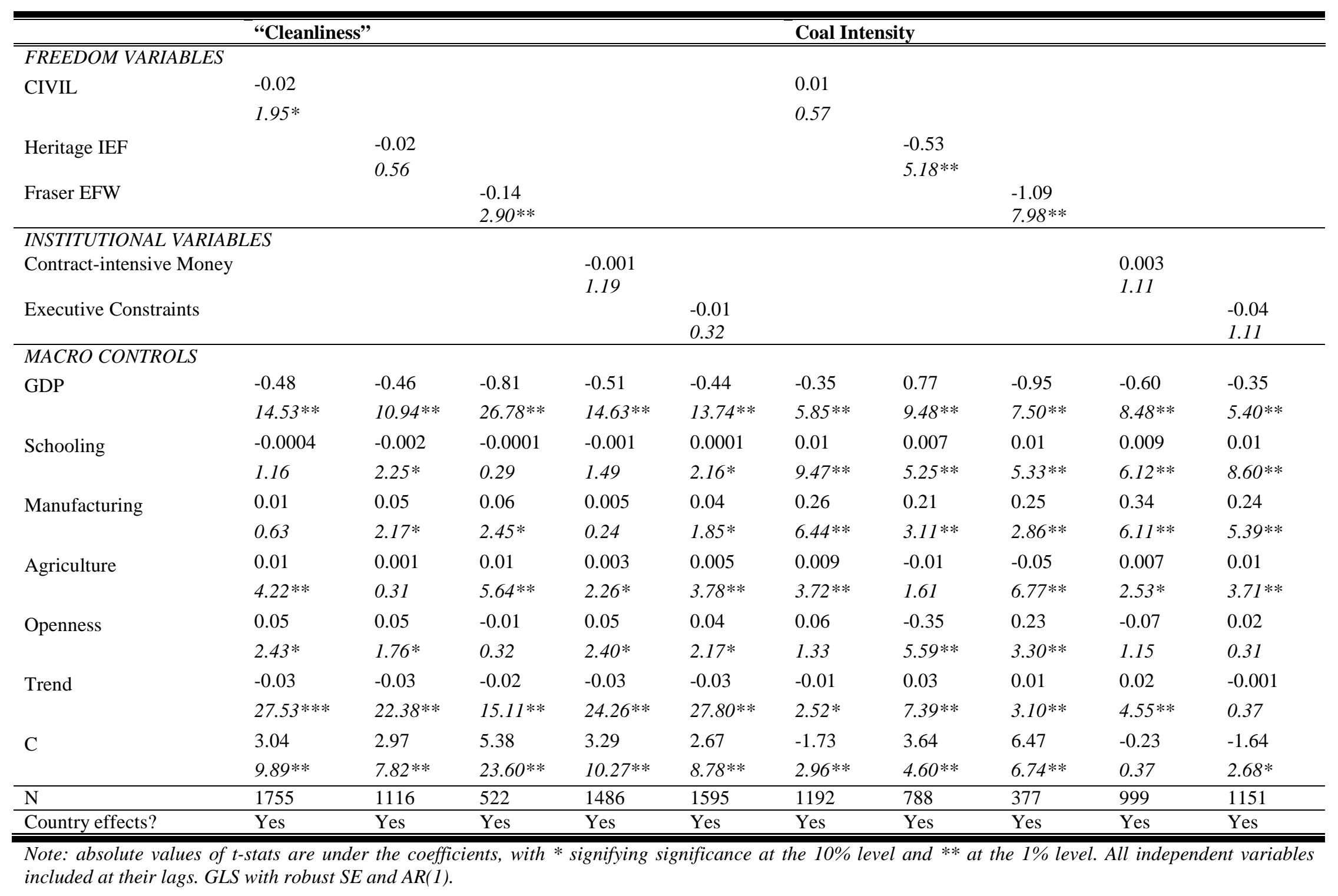


Table 3b. Environmental outcomes as a function of freedom and institutions

\begin{tabular}{|c|c|c|c|c|c|c|c|c|c|c|}
\hline \multirow{2}{*}{ FREEDOM VARIABLES } & \multicolumn{5}{|c|}{ Electrical Intensity } & \multicolumn{5}{|c|}{ Gas Intensity } \\
\hline & & & & & & & & & & \\
\hline \multirow[t]{2}{*}{ CIVIL } & -0.08 & & & & & -0.02 & & & & \\
\hline & $3.50 * *$ & & & & & 0.74 & & & & \\
\hline \multirow[t]{2}{*}{ Heritage IEF } & & 0.24 & & & & & -0.48 & & & \\
\hline & & $4.42 * *$ & & & & & $5.21 * *$ & & & \\
\hline \multirow[t]{2}{*}{ Fraser EFW } & & & 0.19 & & & & & -0.16 & & \\
\hline & & & $1.70 *$ & & & & & 0.97 & & \\
\hline \multicolumn{11}{|c|}{ INSTITUTIONAL VARIABLES } \\
\hline \multirow[t]{2}{*}{ Contract-intensive Money } & & & & 0.002 & & & & & -0.001 & \\
\hline & & & & 1.32 & & & & & 0.91 & \\
\hline \multirow[t]{2}{*}{ Executive Constraints } & & & & & 0.05 & & & & & -0.001 \\
\hline & & & & & $2.53 *$ & & & & & 0.03 \\
\hline \multicolumn{11}{|l|}{ MACRO CONTROLS } \\
\hline \multirow[t]{2}{*}{ GDP } & -0.54 & -0.97 & -0.57 & -0.39 & -0.53 & -0.40 & -0.58 & -0.85 & -0.63 & -0.40 \\
\hline & $10.97 * *$ & $9.98 * *$ & $4.89 * *$ & $8.05 * *$ & $10.84 * *$ & $5.45^{* *}$ & $5.90^{* *}$ & $5.35 * *$ & $7.79 * *$ & $5.26 * *$ \\
\hline \multirow[t]{2}{*}{ Schooling } & 0.008 & 0.002 & 0.006 & 0.005 & 0.01 & 0.008 & 0.005 & 0.003 & 0.009 & 0.008 \\
\hline & $8.54 * *$ & $2.27 *$ & $3.86^{* *}$ & $6.02 * *$ & $8.51 * *$ & $7.91 * *$ & $7.07 * *$ & $3.31 * *$ & $7.56^{* *}$ & $7.54 * *$ \\
\hline \multirow[t]{2}{*}{ Manufacturing } & 0.15 & 0.10 & 0.35 & 0.06 & 0.11 & 0.36 & 0.21 & 0.36 & 0.33 & 0.35 \\
\hline & $4.70^{* *}$ & $2.70 * *$ & $5.94 * *$ & $2.33 *$ & $5.07 * *$ & $6.47^{* *}$ & $3.49 * *$ & $3.74 * *$ & $5.44 * *$ & $5.90 * *$ \\
\hline \multirow[t]{2}{*}{ Agriculture } & -0.005 & -0.008 & -0.03 & 0.003 & -0.005 & 0.004 & -0.08 & -0.05 & -0.001 & 0.005 \\
\hline & $2.68 * *$ & $2.49 *$ & $5.70^{* *}$ & 1.41 & $2.25 *$ & 1.19 & $1.80^{*}$ & $6.14 * *$ & 0.12 & 1.30 \\
\hline \multirow[t]{2}{*}{ Openness } & 0.06 & 0.02 & -0.02 & 0.02 & 0.07 & -0.03 & -0.05 & -0.67 & -0.10 & -0.02 \\
\hline & $2.46^{*}$ & 0.43 & 0.36 & 0.72 & $3.26^{* *}$ & 0.60 & 0.95 & $9.16^{* *}$ & $1.89 *$ & 0.45 \\
\hline \multirow[t]{2}{*}{ Trend } & 0.03 & 0.04 & 0.04 & 0.03 & 0.02 & 0.03 & 0.03 & 0.05 & 0.04 & 0.03 \\
\hline & $15.28 * *$ & $13.47 * *$ & $11.17 * *$ & $18.88 * *$ & $12.65 * *$ & $12.83 * *$ & $8.89 * *$ & $14.19 * *$ & $11.86^{* *}$ & $10.96^{* *}$ \\
\hline \multirow[t]{2}{*}{$\mathrm{C}$} & 2.71 & 4.79 & 3.05 & 1.84 & 2.22 & -10.06 & -5.80 & -5.01 & -8.31 & -10.06 \\
\hline & $2.87 * *$ & $4.92 * *$ & $2.70 * *$ & $1.90 *$ & $2.35 *$ & $15.72 * *$ & $6.85 * *$ & $4.11 * *$ & $11.89 * *$ & $15.11 * *$ \\
\hline $\mathrm{N}$ & 1222 & 797 & 364 & 1078 & 1088 & 1062 & 717 & 341 & 871 & 1032 \\
\hline Country effects? & Yes & Yes & Yes & Yes & Yes & Yes & Yes & Yes & Yes & Yes \\
\hline
\end{tabular}


Table 4a. Environment outcomes as a function of different facets of economic freedom

\begin{tabular}{|c|c|c|c|c|c|c|c|c|c|c|}
\hline \multicolumn{11}{|c|}{ Dependent Variables: Environmental Outcomes } \\
\hline & \multicolumn{5}{|c|}{ "Cleanliness" } & \multicolumn{5}{|c|}{ Coal Intensity } \\
\hline \multicolumn{11}{|c|}{ FRASER INDEX FREEDOM VARIABLES } \\
\hline \multirow[t]{2}{*}{ Size of Government } & 0.001 & & & & & -0.07 & & & & \\
\hline & 0.26 & & & & & $7.52 * *$ & & & & \\
\hline \multirow[t]{2}{*}{ Legal System/Property Rights } & & -0.02 & & & & & -0.0002 & & & \\
\hline & & $5.05 * *$ & & & & & 0.02 & & & \\
\hline \multirow[t]{2}{*}{ Sound Money } & & & 0.009 & & & & & -0.03 & & \\
\hline & & & $2.89 * *$ & & & & & $5.46 * *$ & & \\
\hline \multirow[t]{2}{*}{ Freedom to Trade } & & & & -0.006 & & & & & 0.06 & \\
\hline & & & & 1.59 & & & & & $5.20 * *$ & \\
\hline Regulation & & & & & $\begin{array}{l}0.01 \\
2.83 * *\end{array}$ & & & & & $\begin{array}{l}-0.06 \\
3.80 * *\end{array}$ \\
\hline \multicolumn{11}{|l|}{ MACRO CONTROLS } \\
\hline \multirow[t]{2}{*}{ GDP } & -0.73 & -0.75 & -0.73 & -0.72 & -0.75 & -0.53 & -0.63 & -0.67 & -0.66 & -0.64 \\
\hline & $25.86 * *$ & $28.75 * *$ & $22.33 * *$ & $25.10 * *$ & $29.31 * *$ & $6.49 * *$ & $9.42 * *$ & $11.14 * *$ & $8.82 * *$ & $10.12 * *$ \\
\hline \multirow[t]{2}{*}{ Schooling } & -0.0003 & -0.00004 & -0.00004 & -0.0003 & -0.002 & 0.01 & 0.01 & 0.01 & 0.01 & 0.01 \\
\hline & 0.87 & 0.11 & 1.13 & 0.76 & 0.57 & $9.86 * *$ & $10.16^{* *}$ & $9.44 * *$ & $8.53 * *$ & $8.24^{* *}$ \\
\hline \multirow[t]{2}{*}{ Manufacturing } & 0.05 & 0.06 & 0.04 & 0.05 & 0.06 & 0.37 & 0.39 & 0.36 & 0.35 & 0.40 \\
\hline & $1.87 *$ & $2.48^{*}$ & $1.65 *$ & $2.03 *$ & $2.29 *$ & $5.23 * *$ & $5.22 * *$ & $5.01 * *$ & $4.92 * *$ & $5.13 * *$ \\
\hline \multirow[t]{2}{*}{ Agriculture } & 0.005 & 0.004 & 0.01 & 0.005 & 0.005 & -0.01 & -0.01 & -0.02 & -0.01 & -0.01 \\
\hline & $4.09 * *$ & $3.97 * *$ & $4.61 * *$ & $3.62 * *$ & $5.39 * *$ & $2.25 *$ & $2.45 *$ & $6.06 * *$ & $1.81 *$ & $4.81^{* *}$ \\
\hline \multirow[t]{2}{*}{ Openness } & -0.04 & -0.03 & -0.04 & -0.04 & -0.04 & 0.21 & 0.27 & 0.29 & 0.26 & 0.27 \\
\hline & 1.62 & 1.25 & $1.76^{*}$ & 1.64 & $2.00 *$ & $3.74 * *$ & $4.68 * *$ & $5.31 * *$ & $4.47 * *$ & $4.43 * *$ \\
\hline \multirow[t]{2}{*}{ Trend } & -0.02 & -0.02 & -0.02 & -0.02 & -0.02 & 0.002 & -0.0003 & 0.0005 & 0.001 & 0.003 \\
\hline & $16.71 * *$ & $17.31 * *$ & $16.84 * *$ & $16.90 * *$ & $17.20 * *$ & 0.54 & 0.11 & 0.16 & 0.24 & 0.86 \\
\hline \multirow[t]{2}{*}{$\mathrm{C}$} & 4.83 & 4.97 & 4.60 & 4.73 & 4.73 & 0.56 & 0.62 & 1.53 & 0.58 & 1.15 \\
\hline & $22.68 * *$ & $24.37 * *$ & $17.60 * *$ & $21.58 * *$ & $23.96 * *$ & 0.79 & 1.07 & $2.99 * *$ & 0.92 & $2.21 *$ \\
\hline $\mathrm{N}$ & 948 & 964 & 946 & 945 & 973 & 686 & 696 & 686 & 686 & 698 \\
\hline Country effects? & Yes & Yes & Yes & Yes & Yes & Yes & Yes & Yes & Yes & Yes \\
\hline
\end{tabular}

Note: absolute values of $t$-stats are under the coefficients, with * signifying significance at the $10 \%$ level and ** at the $1 \%$ level. All independent variables included at their lags. GLS with robust SE and AR(1). 
Table 4b. Environment outcomes as a function of different facets of economic freedom

\begin{tabular}{|c|c|c|c|c|c|c|c|c|c|c|}
\hline \multicolumn{11}{|c|}{ Dependent Variables: Environmental Outcomes } \\
\hline & \multicolumn{5}{|c|}{ Electrical Intensity } & \multicolumn{5}{|c|}{ Gas Intensity } \\
\hline \multicolumn{11}{|c|}{ FRASER INDEX FREEDOM VARIABLES } \\
\hline \multirow[t]{2}{*}{ Size of Government } & -0.04 & & & & & -0.04 & & & & \\
\hline & $5.94 * *$ & & & & & $3.58 * *$ & & & & \\
\hline \multirow[t]{2}{*}{ Legal System/Property Rights } & & -0.02 & & & & & 0.02 & & & \\
\hline & & $2.57 * *$ & & & & & $2.17 *$ & & & \\
\hline \multirow[t]{2}{*}{ Sound Money } & & & 0.01 & & & & & -0.04 & & \\
\hline & & & 1.53 & & & & & $4.96 * *$ & & \\
\hline \multirow[t]{2}{*}{ Freedom to Trade } & & & & 0.04 & & & & & 0.02 & \\
\hline & & & & $4.32 * *$ & & & & & $2.97 * *$ & \\
\hline \multirow[t]{2}{*}{ Regulation } & & & & & -0.02 & & & & & -0.03 \\
\hline & & & & & 1.44 & & & & & $2.65 * *$ \\
\hline \multicolumn{11}{|l|}{ MACRO CONTROLS } \\
\hline \multirow[t]{2}{*}{ GDP } & -0.64 & -0.59 & -0.50 & -0.53 & -0.47 & -0.69 & -0.65 & -0.57 & -0.67 & -0.58 \\
\hline & $7.24 * *$ & $7.58 * *$ & $5.32 * *$ & $6.02 * *$ & $5.63 * *$ & $7.15 * *$ & $6.96 * *$ & $6.04 * *$ & $7.09 * *$ & $6.17 * *$ \\
\hline \multirow{2}{*}{ Schooling } & 0.008 & 0.009 & 0.007 & 0.006 & 0.007 & 0.004 & 0.005 & 0.005 & 0.004 & 0.005 \\
\hline & $5.02 * *$ & $5.97 * *$ & $4.26 * *$ & $3.91 * *$ & $4.79 * *$ & $4.98 * *$ & $6.01 * *$ & $6.31 * *$ & $5.02 * *$ & $4.89 * *$ \\
\hline \multirow[t]{2}{*}{ Manufacturing } & 0.38 & 0.42 & 0.36 & 0.32 & 0.34 & 0.43 & 0.46 & 0.39 & 0.40 & 0.45 \\
\hline & $6.76 * *$ & $7.63 * *$ & $6.06 * *$ & $6.15 * *$ & $6.15 * *$ & $6.18 * *$ & $6.91 * *$ & $5.48 * *$ & $5.79 * *$ & $6.46 * *$ \\
\hline \multirow[t]{2}{*}{ Agriculture } & -0.04 & -0.05 & -0.03 & -0.03 & -0.02 & -0.03 & -0.02 & -0.03 & -0.02 & -0.01 \\
\hline & $10.62 * *$ & $19.30 * *$ & $5.39 * *$ & $5.82 * *$ & $5.91 * *$ & $4.61 * *$ & $3.47 * *$ & $4.57 * *$ & $3.12 * *$ & $2.50 *$ \\
\hline \multirow[t]{2}{*}{ Openness } & 0.15 & 0.25 & 0.05 & 0.03 & 0.05 & -0.22 & -0.24 & -0.20 & -0.26 & -0.22 \\
\hline & $2.65 * *$ & $5.02 * *$ & 0.73 & 0.53 & 0.78 & $3.72 * *$ & $4.01 * *$ & $3.23 * *$ & $4.38 * *$ & $3.66 * *$ \\
\hline \multirow[t]{2}{*}{ Trend } & 0.03 & 0.02 & 0.03 & 0.02 & 0.03 & 0.04 & 0.04 & 0.03 & 0.04 & 0.04 \\
\hline & $9.36 * *$ & $7.12 * *$ & $8.60 * *$ & $7.52 * *$ & $8.74 * *$ & $12.72 * *$ & $14.10 * *$ & $11.72 * *$ & $13.61 * *$ & $13.22 * *$ \\
\hline \multirow[t]{2}{*}{$\mathrm{C}$} & 3.86 & 3.43 & 2.17 & 2.46 & 2.18 & -7.00 & -8.03 & -7.72 & -7.73 & -8.25 \\
\hline & $4.00 * *$ & $3.80 * *$ & $2.09 *$ & $2.50 *$ & $2.25 *$ & $8.29 * *$ & $9.85 * *$ & $9.31 * *$ & $9.40 * *$ & $10.00 * *$ \\
\hline $\mathrm{N}$ & 621 & 633 & 619 & 618 & 638 & 645 & 656 & 645 & 645 & 661 \\
\hline Country effects? & Yes & Yes & Yes & Yes & Yes & Yes & Yes & Yes & Yes & Yes \\
\hline
\end{tabular}

Note: absolute values of $t$-stats are under the coefficients, with * signifying significance at the $10 \%$ level and $* *$ at the $1 \%$ level. All independent variables included at their lags. GLS with robust SE and AR(1). 
Table 5. Freedom and environmental outcomes, alternate controls

\begin{tabular}{|c|c|c|c|c|c|}
\hline & "Cleanliness" & Coal Intensity & Electrical Intensity & & Gas Intensity \\
\hline \multicolumn{2}{|c|}{ FREEDOM VARIABLES } & & & & \\
\hline \multirow[t]{2}{*}{ CIVIL } & -0.02 & & 0.008 & & \\
\hline & $2.31 *$ & & 0.39 & & \\
\hline \multirow[t]{2}{*}{ Heritage IEF } & & -0.18 & 0.02 & & -0.37 \\
\hline & & $2.45^{*}$ & 0.35 & & $4.18 * *$ \\
\hline \multirow[t]{2}{*}{ Fraser EFW } & -0.09 & -0.94 & & -0.19 & \\
\hline & $1.94 *$ & $7.80 * *$ & & $2.05 *$ & \\
\hline
\end{tabular}

INSTITUTIONAL VARIABLES

Executive Constraints

0.01

CONTROLS

\begin{tabular}{|c|c|c|c|c|c|c|c|c|c|}
\hline \multirow[t]{2}{*}{ GDP } & -0.44 & -0.85 & -0.58 & -0.08 & -0.28 & -0.41 & -0.06 & -0.25 & -0.29 \\
\hline & $15.75 * *$ & $20.28 * *$ & $7.70 * *$ & 0.98 & $7.27 * *$ & $7.33 * *$ & 0.75 & $6.30 * *$ & $3.06 * *$ \\
\hline \multirow[t]{2}{*}{ Land/Population } & -1.15 & -2.76 & 3.51 & 1.83 & -0.93 & 0.44 & 1.30 & -0.98 & 2.24 \\
\hline & $3.04 * *$ & $5.50 * *$ & $2.51 *$ & $1.78^{*}$ & $2.34 *$ & 0.94 & 1.61 & $2.43^{*}$ & 1.18 \\
\hline \multirow[t]{2}{*}{ Capital/Labor } & -0.0001 & 0.0005 & -0.0002 & -0.0005 & -0.0005 & -0.0003 & -0.0002 & -0.0005 & -0.0004 \\
\hline & 0.34 & 1.46 & 0.19 & $6.76^{* *}$ & $12.60 * *$ & $6.32 * *$ & $4.48 * *$ & $13.35 * *$ & 0.44 \\
\hline \multirow[t]{2}{*}{ Trend } & -0.03 & -0.02 & 0.02 & 0.03 & 0.04 & 0.04 & 0.05 & 0.04 & 0.03 \\
\hline & $30.08 * * *$ & $17.14 * *$ & $5.05 * *$ & $8.20 * *$ & $32.71 * *$ & $27.43 * *$ & $20.02 * *$ & $30.17 * *$ & $6.92 * *$ \\
\hline \multirow[t]{2}{*}{$\mathrm{C}$} & 2.90 & 5.85 & 2.13 & 0.23 & 0.65 & 1.72 & -0.31 & 0.43 & -7.67 \\
\hline & $12.65 * *$ & $18.22 * *$ & $3.54 * *$ & 0.32 & 0.83 & $2.82 * *$ & 0.41 & 0.58 & $10.83 * *$ \\
\hline $\mathrm{N}$ & 2690 & 731 & 1124 & 525 & 1970 & 1214 & 533 & 1755 & 969 \\
\hline Country effects? & Yes & Yes & Yes & Yes & Yes & Yes & Yes & Yes & Yes \\
\hline
\end{tabular}

Note: absolute values of $t$-stats are under the coefficients, with * signifying significance at the $10 \%$ level and ** at the $1 \%$ level.

All independent variables included at their lags. GLS with robust SE and AR(1). 